\title{
PENGARUH INVESTASI TERHADAP PENYERAPAN TENAGA KERJA DI JAWA TENGAH TAHUN 2009-2013
}

\author{
Abdul Haris Romdhoni \\ STIE-AAS Surakarta \\ harisromdhoni27@gmail.com
}

\begin{abstract}
Abstrak
This study aims to determine the effect of investment on employment in Central Java in 2009-2013. As it is known that investment plays an important role in the absorption of labor or can reduce unemployment. Thus with the increased investment hence the absorption of labor will also increase. The research method used in this research is quantitative research method. This research was conducted in Central Java. The test used is the instrument using the validity test. Methods of data analysis using multiple linear regression analysis, classical assumption test. The results of this study indicate that the increase can be explained by the regression equation is $\mathrm{Y}=16595732.325+0.32$ $\mathrm{X}$. Where the constant is positive value of 16595732.325 indicates that if the investment variable is considered constant (0), then the value of labor absorption of 16595732,325. Then the regression coefficient of the investment variable is 0.32 , this means that if the investment is increased one unit, it will increase the labor absorption of 0.32 .
\end{abstract}

Keywords: investment, employment.

\section{Pendahuluan}

Pembangunan ekonomi adalah proses mengubah struktur ekonomi yang belum berkembang dengan jalan capital investment dan human investment yang bertujuan untuk meningkatkan kemakmuran penduduk atau income per capita naik (Hasibuan, 1987: 12). Menurut Suparmoko (2002:5), pembangunan ekonomi adalah usaha-usaha untuk meningkatkan taraf hidup suatu bangsa yang seringkali diukur dengan tinggi rendahnya pendapatan riil perkapita. Sementara pemberlakuan otonomi daerah di Indonesia membawa perubahan tersendiri bagi tata kelola pemerintahan. Otonomi daerah dapat memberikan keseimbangan pengelolaan sumber daya (resources) yang selama ini disinyalir hanya terakumulasi di Pemerintahan Pusat, maka dalam paket otonomi daerah terdapat paket Undang-Undang No.32 Tahun 2004 tentang Pemerintahan Daerah dan Undang-Undang No. 33 Tahun 2004 tentang
Perimbangan Keuangan Pusat dan Daerah. Tentu saja undang-undang yang terkait dengan otonomi daerah tidak hanya kedua undangundang tersebut, seperti Undang-Undang No.6 Tahun 2014 tentang Desa. Kesemuanya adalah untuk memberikan peluang kepada daerah untuk mengelola potensi yang dimilikinya supaya kesejahteraan perekonomian dapat meningkat.

$$
\text { Allen dalam Kuncoro }
$$
mengemukakan, sejarah perekonomian telah mencatat desentralisasi telah muncul sebagai paradigma baru dalam kebijakan dan administrasi pembangunan. Ketidakpastian yang tidak dapat dengan penuh dikendalikan dan direncanakan dari pusat. Semenjak dilaksanakannya UU Otonomi Daerah, banyak perubahan yang terjadi pada penyelenggaraan pemerintahan daerah. Juga memberikan perubahan pada hubungan pemerintah pusat dan daerah, yaitu perubahan sistem pemerintahan dari bentuk sentralistis menjadi 
desentralistis, dalam arti adanya pengalihan sebagian besar wewenang pemerintahan dari pemerintah pusat kepada pemerintah daerah. Adapun wewenang yang tetap menjadi otoritas pemerintah pusat adalah di bidang politik luar negeri, pertahanan dan keamanan, peradilan, moneter, serta agama.

Perkembangan dan kemajuan dari suatu daerah dapat dilihat dari produk domestik regional bruto (PDRB). PDRB adalah sejumlah nilai tambah produksi yang ditimbulkan oleh beberapa sektor atau lapangan usaha dalam suatu wilayah yang melakukan kegiatan usahanya di suatu daerah ata regional tanpa memilih atas faktor produksi. Dengan dimikian tingkat PDRB dapat menggambarkan pertumbuhan ekonomi suatu daerah. Tingginya tingkat pertumbuhan ekonomi yang ditunjukkan dengan tingginya nilai PDRB menunjukkan bahwa daerah tersebut mengalami kemajuan dalam perekonomian. PDRB akan memperlihatkan kontribusi masing-masing sektor terhadap pertumbuhan ekonomi. Besarnya kontribusi PDRB yang dimiliki seharusnya dapat berpengaruh dalam penyerapan tenaga kerja.Hukum Okun menyatakan bahwa terdapat hubungan yang erat antara tingkat pengangguran dengan Gross Domestic Bruto (GDP). Tingkat pengangguran dengan GDP riil memiliki hubungan yang negatif (Mankiw, 2007).

PDRB Propinsi Jawa Tengah Tahun 2004-2008 menunjukkan bahwa kontribusi terbesar dalam PDRB adalah sektor industri dan yang kedua adalah sektor pertanian (selengkapnya lihat tabel 1.1). Pada tabel 1.1 dapat dilihat bahwa sektor yang mempunyai kontribusi terbesar pada PDRB Jawa Tengah Tahun 2004-2008 adalah sektor industri pengolahan, sedangkan urutan kedua terbesar adalah pada sektor pertanian. Di samping itu kontribusi kedua sektor tersebut juga terus mengalami kenaikan dari tahun ke tahun. Dengan besarnya kontribusi kedua sektor tersebut pada PDRB, maka diduga kuat sektor tersebut juga membawa pengaruh atau keterkaitan ke depan maupun ke belakang (forward and backward lingkages). Selain itu, sektor ini juga dapat dijangkau oleh berbagai kalangan karena banyak yang bersifat padat karya dan seharusnya dapat menyerap tenaga kerja lebih tinggi dibandingkan dengan sektor lainnya, sehingga dalam penelitian ini akan meneliti faktor-faktor yang mempengaruhi penyerapan tenaga kerja pada sektor industri pengolahan dan sektor pertanian serta untuk mengetahui dampak penyerapan tenaga kerja pada kedua sektor tersebut.

Tabel 1. PDRB Jawa Tengah Tahun 2009 - 2013

\begin{tabular}{|l|r|r|r|r|r|}
\hline \multicolumn{1}{|c|}{ LAPANGAN USAHA } & \multicolumn{1}{|c|}{2009} & \multicolumn{1}{c|}{2011} & \multicolumn{1}{c|}{2012} & 2013 \\
\hline 1. PERTANIAN & $79,342,553.91$ & $86,665,684.94$ & $95,078,348.99$ & $104,311,416.83$ & $113,922,758.60$ \\
\hline $\begin{array}{l}\text { 2. PERTAMBANGAN \& } \\
\text { PENGGALIAN }\end{array}$ & $3,852,796.77$ & $4,302,563.07$ & $4,726,493.18$ & $5,243,452.92$ & $5,951,264.02$ \\
\hline 3. INDUSTRI PENGOLAHAN & $130,352,154.42$ & $146,132,837.59$ & $165,850,520.22$ & $182,715,245.06$ & $203,104,060.25$ \\
\hline 4. LISTRIK, GAS \& AIR BERSIH & $4,114,517.64$ & $4,645,499.82$ & $5,110,058.36$ & $5,648,692.00$ & $6,599,849.53$ \\
\hline 5. BANGUNAN & $24,448,721.40$ & $27,124,582.63$ & $29,851,905.75$ & $33,352,512.04$ & $37,196,092.85$ \\
\hline $\begin{array}{l}\text { 6. PERDAGANGAN, HOTEL \& } \\
\text { RESTORAN }\end{array}$ & $78,262,543.48$ & $86,996,495.32$ & $98,462,085.40$ & $112,908,719.28$ & $129,303,763.70$ \\
\hline $\begin{array}{l}7 . \text { PENGANGKUTAN \& } \\
\text { KOMUNIKASI }\end{array}$ & $23,836,789.16$ & $26,298,747.14$ & $29,172,039.07$ & $32,951,087.21$ & $37,611,878.39$ \\
\hline
\end{tabular}


JURNAL ILMIAH EKONOMI ISLAM VOL. 03 NO. 02, 2017

Available at http://jurnal.stie-aas.ac.id/index.php/jie

\begin{tabular}{|c|r|r|r|r|r|}
\begin{tabular}{|} 
8. KEUANGAN, PERSEWAAN \& \\
JASA PERUSAHAAN
\end{tabular} & $14,447,437.07$ & $15,899,731.16$ & $17,684,047.74$ & $19,993,405.95$ & $23,280,361.13$ \\
\hline $\begin{array}{c}\text { 9. JASA-JASA } \\
\text { PRODUK DOMESTIK REGIONAL } \\
\text { BRUTO }\end{array}$ & $39,246,429.89$ & $46,599,865.32$ & $52,828,325.46$ & $59,359,199.44$ & $66,530,164.90$ \\
\hline
\end{tabular}

Sumber : Badan Pusat Statistik Jawa Tengah

Tabel 2. Nilai Investasi Menurut Jenis Industri di Jawa Tengah Tahun 2009 - 2013

\begin{tabular}{|c|c|c|c|c|c|c|}
\hline \multicolumn{2}{|c|}{$\begin{array}{l}\text { Jenis Industri } \\
\text { Kind of Industry }\end{array}$} & 2009 & 2010 & 2011 & 2012 & 2013 \\
\hline 01. & Agro Industri & $4,061,861$ & $3,943,292$ & $5,280,875$ & $8,716,491$ & $7,328,851$ \\
\hline- & Besar & $3,473,537$ & $3,390,318$ & $4,540,329$ & $5,164,034$ & $4,368,022$ \\
\hline - & $\begin{array}{l}\text { Kecil dan } \\
\text { Menengah }\end{array}$ & 588,324 & 552,974 & 740,546 & $3,552,457$ & $2,960,829$ \\
\hline 02. & Industri & $5,258,602$ & $9,992,216$ & $13,381,623$ & $19,518,424$ & $16,440,878$ \\
\hline- & Besar & $4,328,669$ & $9,118,102$ & $12,211,005$ & $13,962,017$ & $11,809,839$ \\
\hline- & $\begin{array}{l}\text { Kecil dan } \\
\text { Menengah }\end{array}$ & 929,933 & 874,114 & $1,170,618$ & $5,556,407$ & $4,631,039$ \\
\hline Jumlah & - Besar & $7,802,206$ & $12,508,420$ & $16,751,334$ & $19,126,051$ & $16,177,861$ \\
\hline- & $\begin{array}{l}\text { Kecil dan } \\
\text { Menengah }\end{array}$ & $1,518,257$ & $1,427,089$ & $1,911,164$ & $9,108,864$ & $7,591,868$ \\
\hline- & Total & $9,320,463$ & $13,935,509$ & $18,662,498$ & $28,234,915$ & $23,769,729$ \\
\hline
\end{tabular}

Sumber : Badan Pusat Statistik Provinsi Jawa Tengah

Tabel 3. Jumlah Angkatan Kerja Jawa Tengah 2009-2013

\begin{tabular}{|c|c|c|c|c|c|}
\hline \multirow{3}{*}{ Wilayah Jateng } & \multicolumn{5}{|c|}{ Jumlah Angkatan Kerja } \\
\hline & \multicolumn{5}{|c|}{ Total Angkatan Kerja } \\
\hline & 2009 & 2010 & 2011 & 2012 & 2013 \\
\hline JAWA TENGAH & 17087649 & 16856330 & 17026107 & 17513488 & 17524022 \\
\hline Kabupaten Cilacap & 778660 & 762347 & 760925 & 788335 & 809796 \\
\hline Kabupaten Banyumas & 740042 & 792012 & 756728 & 770807 & 765216 \\
\hline Kabupaten Purbalingga & 421467 & 435598 & 455167 & 484481 & 473482 \\
\hline Kabupaten Banjarnegara & 453660 & 467074 & 482535 & 516009 & 483125 \\
\hline Kabupaten Kebumen & 606340 & 584684 & 611511 & 641629 & 614356 \\
\hline Kabupaten Purworejo & 359011 & 353027 & 349190 & 361300 & 378607 \\
\hline Kabupaten Wonosobo & 395068 & 397392 & 411316 & 422907 & 389572 \\
\hline Kabupaten Magelang & 631689 & 648484 & 644895 & 674570 & 644755 \\
\hline Kabupaten Boyolali & 542533 & 527581 & 514048 & 531775 & 544996 \\
\hline Kabupaten Klaten & 617172 & 574549 & 621103 & 634628 & 644722 \\
\hline Kabupaten Sukoharjo & 451417 & 432526 & 438477 & 439739 & 442665 \\
\hline Kabupaten Wonogiri & 580035 & 519702 & 503913 & 537463 & 533914 \\
\hline Kabupaten Karanganyar & 455446 & 457756 & 450538 & 453885 & 452900 \\
\hline Kabupaten Sragen & 494956 & 483526 & 475608 & 501089 & 490389 \\
\hline
\end{tabular}

JURNAL ILMIAH EKONOMI ISLAM, ISSN: 2477-6157 ; E-ISSN 2579-6534 
JURNAL ILMIAH EKONOMI ISLAM VOL. 03 NO. 02, 2017

Available at http://jurnal.stie-aas.ac.id/index.php/jie

\begin{tabular}{|c|c|c|c|c|c|}
\hline Kabupaten Grobogan & 767310 & 721475 & 737143 & 741461 & 728775 \\
\hline Kabupaten Blora & 491863 & 466977 & 458911 & 470992 & 484848 \\
\hline Kabupaten Rembang & 320318 & 320291 & 345704 & 343985 & 340675 \\
\hline Kabupaten Pati & 639265 & 620602 & 636550 & 652640 & 660007 \\
\hline Kabupaten Kudus & 439215 & 420513 & 440537 & 453098 & 449018 \\
\hline Kabupaten Jepara & 558008 & 562402 & 586522 & 598795 & 596921 \\
\hline Kabupaten Demak & 524939 & 522266 & 530756 & 553648 & 545910 \\
\hline Kabupaten Semarang & 510942 & 536204 & 543129 & 558126 & 550015 \\
\hline Kabupaten Temanggung & 389255 & 410860 & 408630 & 422247 & 424768 \\
\hline Kabupaten Kendal & 518428 & 473515 & 478641 & 499395 & 499333 \\
\hline Kabupaten Batang & 347665 & 377700 & 385186 & 389167 & 386503 \\
\hline Kabupaten Pekalongan & 430475 & 418843 & 443290 & 438421 & 430726 \\
\hline Kabupaten Pemalang & 647167 & 581757 & 580412 & 623164 & 613194 \\
\hline Kabupaten Tegal & 650691 & 632931 & 651073 & 648272 & 635852 \\
\hline Kabupaten Brebes & 839546 & 884757 & 800671 & 816021 & 937100 \\
\hline Kota Magelang & 65970 & 61945 & 65991 & 64324 & 63880 \\
\hline Kota Surakarta & 275546 & 258573 & 263562 & 278535 & 287511 \\
\hline Kota Salatiga & 88342 & 81674 & 90689 & 93736 & 94405 \\
\hline Kota Semarang & 787565 & 796186 & 845868 & 846076 & 854170 \\
\hline Kota Pekalongan & 145890 & 145149 & 143545 & 148322 & 142797 \\
\hline Kota Tegal & 121753 & 125452 & 113343 & 114446 & 129119 \\
\hline
\end{tabular}

Sumber : Badan Pusat Statistik Jawa Tengah

\section{Rumusan Masalah}

Berdasarkan paparan di atas dapat dirumuskan masalah penelitian sebagai berikut:

1. Faktor-faktor apakah yang mempengaruhi penyerapan tenaga kerja pada sektor industri pengolahan di Propinsi Jawa Tengah tahun 2004-2008.

2. Bagaimana dampak dari penyerapan tenaga kerja pada sektor industri pengolahan terhadap PDRB Propinsi Jawa Tengah tahun 2004-2008.

\section{Tujuan Penelitian}

Penelitian ini mempunyai tujuan sebagai berikut

1. Untuk mengetahui faktor-faktor yang mempengaruhi penyerapan tenaga kerja pada sektor industri pengolahan di Propinsi Jawa Tengah tahun 2004-2008.

2. Untuk mengetahui dampak dari penyerapan tenaga kerja pada sektor industri pengolahan terhadap PDRB Propinsi Jawa Tengah tahun 2004-2008.

\section{Landasan Teori}

Ada beberapa penelitian yang berhubungan dengan PDRB dan penyerapan tenaga kerja, seperti yang diteliti oleh Alexandi dan Marshafeni yang berjudul Penyerapan Tenaga Kerja pada Sektor Pertanian dan Sektor Jasa Pascakebijakan Upah Minimum Di Provinsi Banten (Periode Tahun 2001-2011). Dalam penelitian ini ditemukan bahwa sektor pertanian memberikan kontribusi penyerapan tenaga kerja terbesar di Provinsi Banten selama periode 2001-2001, namun terus mengalami penurunan hingga tahun 2011.

Faktor-faktor yang mempengaruhi penyerapan tenaga kerja sektor pertanian dan sektor jasa di Provinsi Banten adalah sebagai berikut. Hasil estimasi model sektor pertanian menunjukan bahwa variabel UMK, konsumsi, investasi, dan PDRB memiliki pengaruh yang signifikan dalam penyerapan tenaga kerja di sektor pertanian.Variabel UMK dan investasi memiliki hubungan yang negatif dengan 
penyarapan tenaga kerja di sektor pertanian sedangkan variabel konsumsi dan PDRB memiliki hubungan yang positif. Hasil estimasi model sektor jasa menunjukan bahwa variabel UMK, konsumsi, investasi, dan PDRB memiliki pengaruh yang signifikan dalam penyerapan tenaga kerja di sektor pertanian.Variabelvariabel tersebut memiliki hubungan yang positif dengan penyerapan tenaga kerja di sektor jasa.

Di samping itu Dimas dan Woyanti juga meneliti tentang Penyerapan Tenaga Kerja di DKI Jakarta. Dalam penelitian tersebut dijelaskan bahwa hasil regresi terhadap tiga variabel independen dengan menggunakan model regresi berganda, dengan metode tersebut maka dapat ditarik hasilnya sebagai berikut:

1. Berdasarkan regresi utama variabel independen, yaitu : PDRB (X1), tingkat upah riil (X2), investasi riil (X3) secara bersamasama berpengaruh secara signifikan terhadap penyerapan tenaga kerja di DKI Jakarta. Secara parsial, variabel PDRB (X1), tingkat upah riil (X2) dan investasi riil (X3) berpengaruh secara signifikan pada derajat 1 persen terhadap penyerapan tenaga kerja di DKI Jakarta. Nilai koefisien menunjukkan bahwa apabila PDRB meningkat sebesar satu persen maka penyerapan tenaga kerja meningkat 1,23 persen. Jika upah meningkat 1 persen maka akan menurunkan penyerapan tenaga kerja sebesar 0,20 persen. Jika investasi naik sebesar 1 persen maka akan menurunkan penyerapan tenaga kerja sebesar 0,44 persen.

2. Berdasarkan pengujian asumsi klasik menunjukkan bahwa tidak terdapat autokorelasi antar variabel, tidak terdapat heteroskedastisitas dan tidak terdapat multikolinearitas.

Terakhir hasil penelitian dari Sefle, Naukoko dan Kawung yang meneliti tentang Analisis Faktor-Faktor yang Mempengaruhi
Investasi Di Kabupaten Sorong (Studi pada Kabupaten Sorong Tahun 2008-2012). Dipaparkan dalam hasil penelitiannya bahwa ekonomi merupakan salah satu faktor yang terpenting untuk menyebutkan suatu negara mempunyai power. Pertumbuhan ekonomi yang semakin baik dari setiap waktunya akan memperbaiki sistem pembangunan yang semakin baik. Dalam perekonomian suatu negara/daerah diketahui dari kenaikan Produk Domestik Regional Bruto (PDRB) ada juga beberapa faktor yang mempengaruhi pertumbuhan ekonomi diantaranya sebagai berikut :

1. Tanah dan kekayaan alam lainya

2. Jumlah dan kualitas dari penduduk dan tenaga kerja

3. Barang-barang Modal dan Teknologi.

Dengan PDRB, tenaga kerja, dan suku bunga sebagai variabel yang mempengaruhi investasi di Kabupaten Sorong. Pengujian dengan analisis regresi berganda melalui tiga variabel bebas yakni tenaga kerja, PDRB, tingkat suku bunga tidak dapat di lakukan uji analisis regresi berganda karena terjadianya gejala mulitkolinieritas dalam model, sehingga dengan perbaikan model dengan ceteris paribus, maka pada akhirnya menyisakan variabel PDRB dan Investasi sebagai variabel independen yang bebas dari multikolinieritas. Data yang digunakan dalam dalam perbaikan multikolinieritas penelitian ini terdistribusi normal, dan bebas dari autokorelasi dan heterokedastisitas. Hasil uji $\mathrm{t}$ menunjukkan bahwa variabel PDRB memiliki pengaruh terhadap investasi kabupaten kota sorong. Hasil uji F menunjukkan bahwa PDRB memiliki pengaruh terhadap Investasi.

\section{Investasi}

Investasi adalah pengaitan sumbersumber dalam jangka panjang untuk 
menghasilkan laba di masa yang akan datang (Mulyadi, 2001:284). Investasi juga dapat didefinisikan sebagai penanaman modal atau pemilikan sumber-sumber dalam jangka panjang yang akan bermanfaat pada beberapa periode akuntansi yang akan datang (Supriyono, 1987:424). Investasi dapat pula didefinisikan sebagai penempatan sejumlah dana pada saat ini dengan harapan untuk memperoleh keuntungan di masa mendatang (Halim, 2003:2). Sedangkan menurut Puspitaningtyas dan Kurniawan (2012) investasi dapat diartikan sebagai suatu kegiatan menempatkan sejumlah dana pada satu atau lebih dari satu aset selama periode tertentu dengan harapan dapat memperoleh penghasilan atau peningkatan nilai investasi.

Tujuan investor melakukan kegiatan investasi ialah untuk mencari (memperoleh) pendapatan atau tingkat pengembalian investasi (return) yang akan diterima di masa depan. Di sisi lain risiko (risk) juga melekat pada setiap aktifitas investasi, sehingga mengambil keputusan dalam berinvestasi perlu dipertimbangkan dengan cermat. Menurut Sartono (2001), keputusan investasi menyangkut tentang keputusan alokasi dana baik dana yang berasal dari dalam perusahaan maupun dana yang berasal dari luar perusahaan pada berbagai bentuk investasi. Keputusan investasi juga disebut dengan keputusan penganggaran modal, karena sebagian besar perusahaan mempersiapkan anggaran tahunan yang terdiri dari investasi modal yang disahkan (Brealey, Myers, dan Marcus, 2008:4).

Investasi juga dapat diartikan sebagai pengeluaran atau pembelanjaan penanaman modal atau perusahaan untuk membeli barangbarang produksi, untuk menambah kemampuan memproduksi barang dan jasa yang tersedia dalam perekonomian yang berasal dari investasi dalam negeri maupun inestasi asing. Secara umum terdapat dua jenis investasi, yaitu :
1. Investasi yang terdorong (Induced Invesment)

Investasi yang terdorong (induced Invesment), yakni investasi yang idak diadakan akibat adanya penambahan perminntaan, pertambahan permintaan yang di akibatkan pertambahan pendapatan. Jelasnya apabila pendapatan bertambah, maka tambahan permintaan akan di gunakan untuk konsumsi, sedang pertambahan konsumsi pada dasarnya adalah tambahan permintaan. Sudah pasti apabila ada tambahan permintaan, maka akan mendorong berdirinya pabrik baru atau memperluas pabrik lama untuk dapat memenuhi tambahan permintaan tersebut.

2. Investasi otonom (Outonomous Invesment) Investasi otonom (Outonomous Invesment), yaitu investasi yang di laksanakan atau diadakan secara bebas, artinya investasi yang di adakan bukan karena pertambahan permintaan efektif, tetapi justru untuk menciptakan atau menaikkan permintaan efektif. Besarnya investasi otonom tidak tergantung kepada besar kecilnya pendapatan nasional atau daerah.Investasi otonom berarti pembentukan modal yang tidak di pengaruhi oleh pendapatan naasional. Dengan kata lain, tinggi rendahnya pendapatan nasional tidak menentukan jumlah investasi yang di lakukan oleh perusahaanperusahaan.(Sukirno 2004: 108)

\section{Produk Domestik Regional Bruto (PDRB)}

Salah satu cara untuk melihat kemajuan perekonomian suatu daerah adalah dengan mencermati nilai Produk Domestik Regional Bruto (PDRB). Sedangkan pertumbuhan ekonomi adalah sebagian dari perkembangan kesejahteraan masyarakat yang diukur dengan besarnya pertumbuhan produk domestik regional bruto perkapita (PDRB perkapita) (Zaris, 1987: 82). PDRB merupakan nilai dari 
seluruh barang dan jasa yang diproduksi dalam jangka waktu tertentu biasanya dalam waktu satu tahun disuatu wilayah tertentu.

$$
\text { Sedangkan Daryono }
$$

menyatakan PDRB pada hakekatnya mengambarkan tingkat kegiatan perekonomian suatu daerah, baik yang dilakukan oleh masyarakat, swasta, maupun pemerintah dalam suatu periode tertentu, meliputi seluruh hasil produksi atau output yang diciptakan oleh suatu daerah, sehingga PDRB secara tidak langsung dapat digunakan sebagai indikator dalam menilai hasil kegiatan pembangunan ekonomi daerah secara keseluruhan.

Pertumbuhan ekonomi daerah dari tahun ke tahun dapat dilihat melalui besaran PDRB baik berdasarkan harga berlaku maupun berdasarkan harga konstan. PDRB atas dasar harga berlaku menggambarkan nilai tambah dan barang dan jasa yang menggunakan harga pada setiap tahun, sedangkan PDRB atas dasar harga konstan menunjukkan nilai tambah barang dan jasa yang dihitung menggunakan harga pada tahun tertentu sebagai dasar, yang menunjukkan pertumbuhan ekonomi daerah secara riil, karena telah dikurangi atau diperhitungkan faktor inflasi (Daryono, 2007).

Sedangkan faktor-faktor produksi yang digunakan dalam proses produksi tersebut PDRB diperoleh dari produksi seluruh sektor perekonomian regional yang dijabarkan dalam 9 (Sembilan) sektor dan terakumulasi dalam 3 (tiga) kelompok menurut jenisnya, yaitu :

1. Kelompok primer, adalah sektor yang langsung menghasilkan barang jadi (final product). Terdiri dari sektor pertanian dan sektor pertambangan dan penggalian.

2. Kelompok sekunder, adalah sektor yang dalam menghasilkan barang harus melalui proses pengolahan terlebih dahulu. Terdiri dari sektor industry pengolahan, sektor listrik, gas dan air bersih, dan sektor bangunan.
3. Selanjutnya sektor tersier, adalah sektor yang bergerak dibidang pelayanan (jasa) yang terdiri dari sektor perdagangan, hotel, dan restoran, sektor angkutan dan komunikasi, dan sektor keuangan, persewaan, dan jasa perusahaan dan sektor jasa-jasa(Malikkhan dalam Amir Hamid : 1639).

\section{Tenaga kerja (man power)}

Tenaga kerja merupakan salah satu indikator untuk melihat perkembangan dan kondisi ekonomi suatu daerah. Menurut Todaro (2000 : 56) pertumbuhan penduduk dan pertumbuhan Angkatan Kerja (AK) secara tradisional dianggap sebagai salah satu faktor positif yang memacu pertumbuhan ekonomi. Jumlah tenaga kerja yang lebih besar berarti akan menambah tingkat produksi.

Simanjuntak (2001) menyatakan bahwa tenaga kerja adalah penduduk yang sudah atau sedang bekerja, yang sedang mencari pekerjaan, dan melakukan kegiatan lain seperti bersekolah atau mengurus rumah tangga, dengan batasan umur 15 tahun. Senada dengan pengertian di atas Ananta (1990) dan Ignatia-Nachrowi (2004) bahwa tenaga kerja adalah sebagian dari keseluruhan penduduk yang secara potensial dapat menghasilkan barang dan jasa.

Angkatan kerja dalam suatu perekonomian digambarkan sebagai penawaran tenaga kerja yang tersedia dalam pasar tenaga kerja. Bellante \& Mark (dalam Ignatia, 2004) menyatakan bahwa penawaran kerja dipengaruhi oleh tiga komponen, yaitu: jumlah populasi di suatu wilayah, persentase angkatan kerja, dan jam kerja. Bellante dan Janson (2006) mengemukakan dalam dunia kerja atau dalam hal penyerapan tenaga kerja setiap sektornya berbeda-beda untuk penyerapan tenaga kerjanya, misalnya saja tenaga kerja di sektor formal. Penyeleksian tenaga kerjanya di butuhkan suatu keahlian khusus, pendidikan, 
keahlian dan pengalaman untuk bisa bekerja pada sektor formal.

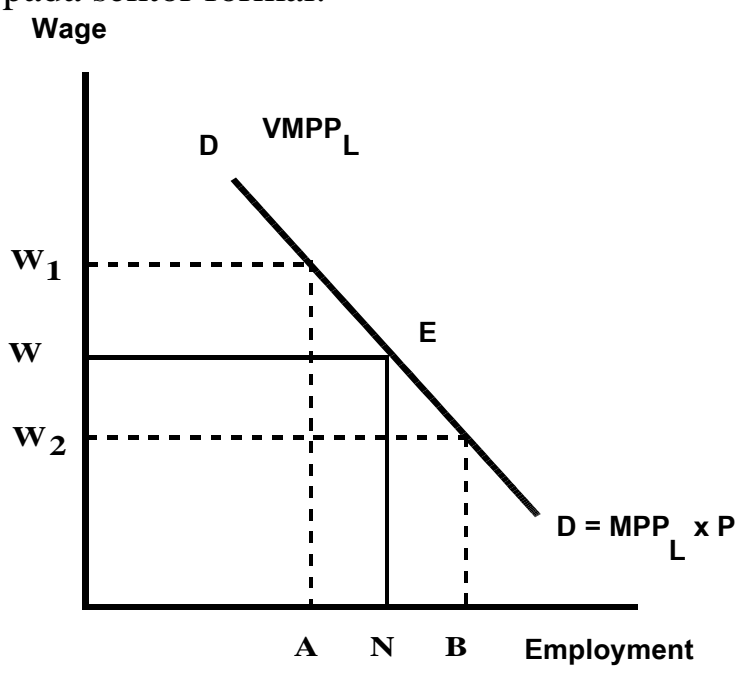

Dari grafik di atas dapat dilihat bahwa hubungan antara tingkat upah dengan tenaga kerja berhubungan negatif. Pada grafik terlihat bahwa ketika $\mathrm{W}_{1}$ maka pada garis tenaga kerja sebesar A, namun pada saat $\mathrm{W}$ turun menjadi $\mathrm{W}_{2}$ justru tenaga kerja naik sebesar B sedangkan tingkat permintaan keseimbangan terletak pada titik $\mathrm{W}$ dan $\mathrm{E}$.

\section{Metodologi Penelitian}

Analisis deskriptif digunakan untuk memberikan penjelasan tentang ketenagakerjaan pada sektor industri dan sektor pertanian. Langkah selanjutnya adalah mendeskripsi variabel-variabel yang terdapat dalam penelitian ini adalah variabel dependen pada penyerapan tenaga kerja, yakni jumlah orang yang bekerja di Propinsi Jawa Tengah yang dapat terserap dalam pasar tenaga kerja pada berbagai tingkat upah. Sedangkan variabel independen, terdiri dari:

1. Produk Domestik Regoinal Bruto (PDRB) yakni jumlah barang dan jasa yang dihasilkan oleh seluruh kegiatan ekonomi di Propinsi Jawa Tengah tahun 2009-2013.

2. Angkatan kerja di Propinsi Jawa Tengah Tahun 2009-2013

3. Investasi yakni pengeluaran riil yang dilakukan oleh perusahaan untuk menambah stok modal yang akan digunakan dalam proses produksi.

Data panel merupakan gabungan antara data cross section dan data time series. Data cross section merupakan data yang dikumpulkan dalam satu waktu terhadap banyak individu sedangkan data time series merupakan data yang dikumpulkan dari waktu ke waktu terhadap suatu individu (Gujarati, 2004). Sedangkan data yang digunakan adalah dari Propinsi Jawa Tengah yang terdiri dari 35 kabupaten/kota.

Sedangkan menurut Baltagi (2005), keunggulan dari menggunakan analisis data panel antara lain sebagai berikut:

1. Mengontrol heterogenitas data individual dalam suatu periode waktu.

2. Memberikan informasi yang lebih luas, mengurangi kolinearitas di antara variabel, memperbesar derajat bebas, dan lebih efisien.

3. Dapat menentukan perubahan dinamis (dynamic adjusment)

4. Mengidentifikasi dan mengukur pengaruhpengaruh yang tidak terdeteksi dalam data cross section dan time series saja

5. Digunakan untuk membuat dan menguji model perilaku yang lebih kompleks dibandingkan analisis data cross section atau time series murni.

Pendekatan yang digunakan dalam penelitian ini adalah pendekatan kuantitatif untuk menganalisis pengukuran fenomena ekonomi yang merupakan gabungan antara teori ekonomi (informasi laporan keuangan), model matematika serta statistika yang diklasifikasikan dalam kategori tertentu dengan menggunkan tabel-tabel tertentu guna mempermudah dala menganalisis dengan menggunakan program SPSS 20.0 for windows. Teknik analisis yang digunakan adalah dengan regresi linier berganda.

Analisis linier berganda digunakan untuk hubungan antara satu variabel terikat 
dengan lebih dari satu variabel bebas. Model regresi linier berganda (multiple linier regression method) digunakan untuk mengetahui apakah terdapat pengaruh yang signifikan dari satu variable terikat (dependen) dan lebih dari variabel bebas (independen).

Analisis regresi berganda untuk mengetahui pengaruh antara variable independen adalah zakat produktif dengan variable dependent yaitu tingkat kesejahteraan. Model hubungannya jika disusun dengan persamaan regresi linier adalah sebagai berikut:

$$
\mathrm{Y}=\alpha+\beta_{1} \mathrm{X}_{1}+\varepsilon
$$

Keterangan :

$$
\begin{aligned}
& \mathrm{Y}=\text { tingkat penyerapan } \\
& \text { tenaga kerja } \\
& \alpha \quad=\text { konstanta } \\
& \beta=\text { koefisien regresi, }
\end{aligned}
$$

$\mathrm{X} 1$

$$
=\text { investasi }
$$

Ketetapan fungsi regresi sampel dalam menaksir nilai aktual dapat diukur dari Goodness of fit. Secara statistik, setidaknya ini dapat diukur dari nilai koefisien determinasi, nilai statistik $\mathrm{F}$, dan nilai statistik $\mathrm{t}$, perhitungan statistik disebut signifikan secara statistik apabila nilai uji statistiknya berada dalam daerah kritis (daerah dimana Ho ditolak). Sebalikya disebut tidak signifikan bila nilai uji statistiknya berada dalam daerah dimana Ho diterima. Adapun yang dalam pengujian statistik regresi berganda dapat diketahui dengan cara menguji komponen-komponen di dalamnya, yaitu sebagai berikut:

1. Uji Asumsi Klasik

a. Uji normalitas

Uji data ini dilakukan untuk melihat apakah suatu data terdistribusi secara normal atau tidak. Cara yang paling sering digunakan untuk menentukan apakah suatu model berdistribusi normal atau tidak yaitu dengan melihat pada histogram residual apakah memiliki bentuk seperti lonceng atau tidak. Cara ini bisa tidak akurat karena pengambilan keputusan data berdistribusi normal atau tidak hanya berpatokan pada pengamatan gambar saja. Cara yang lebih akurat untuk menentukan normal atau tidaknya distribusi suatu data dapat menggunakan rasio skewness dan rasio kurtosis. Santoso (2000) mengatakan bahwa Rasio skewness dan rasio kurtosis dapat dijadikan petunjuk apakah suatu data berdistribusi normal atau tidak. Rasio skewness dapat diperoleh dengan membagi nilai skewness dengan standar error skewness. Untuk mencari rasio kurtosis yaitu dengan cara membagi nilai kurtosis dengan standar error kurtosis. Sebagai pedoman, jika rasio kurtosis dan skewness berada antara -2 hingga +2 , maka distribusi data dapat dikatan normal (Hartanto, 2010 : 21).

b. Pengujian Multikolinieritas

Uji multikolinieritas bertujuan untuk menguji apakah model regresi ditemukan adanya korelasi antar variabel bebas (independent). Model regresi yang baik seharusnya tidak terjadi korelasi antar variable independent. Jika variabel independent saling berkorelasi, maka variable-variabel tidak orthogonal. Variabel orthogonal adalah variable independent yang nilai korelasi antar sesama variable independent sama dengan nol (Ghazali, 2006 : 105).

Pada uji korelasi kita menguji multikolinieritas hanya dengan melihat hubungan secara individual antara satu variabel independent dengan variabel independent lainya. Tetapi multikolinieritas bisa juga muncul karena satu atau lebih variabel independent 
merupakan kombinasi linier dengan variabel indepeden lain. Syarat tidak ada multikolinieritas adalah koefisien VIF tidak lebih dari 10.

c. Pengujian Autokorelasi;

Uji autokorelasi bertujuan untuk menguji apakah model regresi linier ada korelasi antara kesalahan pengganggu pada periode $\mathrm{t}$ dengan kesalahan pengganggu $\mathrm{t}$ 1 (sebelumnya). Jika terjadi korelasi, maka terjadi problem autokorelasi. Autokorelasi muncul karena observasi yang berurutan sepanjang waktu berkaitan satu sama lainya. Model regresi yang baik dalah regresi yang bebas dari autokorelasi (Ghazali, 2006 : 110).

Cara yang dapat digunakan untuk mendeteksi ada atau tidaknya autokorelasi antara lain dengan Uji Durbin-Waston (DW Test) (Ghazali, 2006 : 99). Hipotesis yang di uji adalah :

Ho : tidak ada autokorelasi ( $\mathrm{r}=0$ )

$\mathrm{Ha}$ : ada autokorelasi $(\mathrm{r} \neq 0)$

Keterangan pengambilan keputusan ada tidaknya autokorelasi dapat dilihat pada tabel berikut :

d. Pengujian Heteroskedastisitas

Uji heteroskedastisitas bertujuan untuk menguji apakah dalam model regresi terjadi ketidaksamaan variance dari residual satu pengamatan ke pengamatan lain tetap, maka disebut homoskedastisitas dan jika berbeda disebut heteroskedastisitas. Model regresi yang baik adalah yang homoskedastisitas atau tidak terjadi heteroskedastisitas (Ghazali, 2006 : 139). Dalam uji heteroskedastisitas dapat dilihat dengan analisis gambar Scatterplot yang menyatakan model regresi linier berganda tidak terdapat heteroskedastisitas jika :

1. Titik-titik data menyebar diatas dan dibawah atau disekitar angka 0 .
2. Titik-titik data tidak mengumpul hanya diatas atau dibawah saja

3. Penyebaran titik-titik data tidak boleh membentuk pola bergelombang melebar kemudian menyempit dan melebar kembali

4. Penyebaran titik-titik data sebaiknya tidak berpola.

2. Uji determinasi $\left(\mathrm{R}^{2}\right)$

Koefisien determinasi $\left(\mathrm{R}^{2}\right)$ pada intinya mengukur seberapa jauh kemampuan model dan menerangkan variasi variabel dependen. Nilai koefisien determinasi antar 0 - 1. Nilai $\mathrm{R}^{2}$ yang kecil berarti kemampuan variabelvariabel independen dalam menjelaskan variasi variabel dependen sangat terbatas. Nilai yang mendekati satu berarti variabelvariabel independen memberikan hamper semua informasi yang dibutuhkan untuk memprediksi variasi variabel dependen (Ghazali, 2006 : 97).

\section{Pembahasan}

Pembahasan mengenai investasi dan penyerapan tenaga senantiasa menarik untuk dibahas dan diteliti. Hal itu karena kedua hal tersebut sangat berperan dalam perekonomian baik di tingkat regional maupun nasional, sehingga bagaimanapun akan berdampak pada laju pertumbuhan ekonomi.

Berdasarkan data yang diperoleh dari Badan Pusat Statistik Jawa tengah maka akan dianalisis dengan analisis regres sebagai berikut; bahwa secara rata-rata variabel Penyerapan Tenaga Kerja (Y) adalah sebesar 17201519.2000 dengan standar deviasi sebesar 301754.88162. Sedangkan rata-rata variabel independen atau investasi (X) adalah sebesar 18784622.8000 dengan standar deviasi sebesar 7537546.78796. Lebih lengkap dapat dilihat pada tabel 4. 
JURNAL ILMIAH EKONOMI ISLAM VOL. 03 NO. 02, 2017

Available at http://jurnal.stie-aas.ac.id/index.php/jie

Tabel 4.

Descriptive Statistics

\begin{tabular}{|l|c|r|r|}
\hline & \multicolumn{1}{|c|}{ Mean } & \multicolumn{1}{|c|}{ Std. Deviation } & N \\
\hline PenyTK & 17201519.2000 & 301754.88162 & 5 \\
Investasi & 18784622.8000 & 7537546.78796 & 5 \\
\hline
\end{tabular}

Tabel 5

Correlations

\begin{tabular}{|ll|r|r|}
\hline & & PenyTK & Investasi \\
\hline \multirow{2}{*}{ Pearson Correlation } & PenyTK & 1.000 & .806 \\
& Investasi & .806 & 1.000 \\
Sig. (1-tailed) & PenyTK &. & .050 \\
& Investasi & .050 &. \\
$\mathrm{~N}$ & PenyTK & 5 & 5 \\
& Investasi & 5 & 5 \\
\hline
\end{tabular}

Sedangkan dari tingkat signifikansi koefisien korelasi variabel investasi adalah 0,806 sebesar 0,050. Hal itu berarti antara variabel investasi dengan variabel penyerapan tenaga kerja mempunyai hubungan yang positif. Artinya jika investasi naik maka, penyerapan tenaga kerja juga akan naik, begitu pula sebaliknya.

\section{Tabel 5}

Variables Entered/Removed $^{\text {a }}$

\begin{tabular}{|l|l|l|l|}
\hline Model & \multicolumn{1}{|c|}{$\begin{array}{c}\text { Variables } \\
\text { Entered }\end{array}$} & $\begin{array}{c}\text { Variables } \\
\text { Removed }\end{array}$ & Method \\
\hline 1 & Investasi $^{D}$ & & Enter \\
\hline
\end{tabular}

a. Dependent Variable: PenyTK

b. All requested variables entered. 
Dari tabel 5 diatas tidak ditemukan variabel yang ditolak atau dikeluarkan. Dengan kata lain kesemui variabel independen investasi dimasukkan dalan penghitungan regresi.

Tabel 6

Model Summary

\begin{tabular}{|l|r|r|r|r|}
\hline Model & R & R Square & $\begin{array}{c}\text { Adjusted R } \\
\text { Square }\end{array}$ & $\begin{array}{r}\text { Std. Er } \\
\text { Est }\end{array}$ \\
\hline 1 & $.806^{\mathrm{a}}$ & .649 & .532 & $2064^{\circ}$ \\
\hline
\end{tabular}

a. Predictors: (Constant), Investasi

b. Dependent Variable: PenyTK

Berdasarkan tabel 6 bahwa R Square adalal 0,649 (adalah pengkuadratan dari koefisien korelas atau $0,806 \times 0,806=0,649)$. $R$ Square dapa disebut sebagai koefisien determinasi, yang dalam hal ini berarti $64,9 \%$ penyerapan tenaga kerja dapa dijelaskan oleh variabel investasi. Sedangkar sisanya $35.1 \%$ dijelaskan oleh sebab-sebab lain.

Sedangkan standard error of the estimat adalah 206.457,80491 lebih kecil daripada standa deviasi yang sebesar 301.754,88162. Oleh karen: standard error of estimate lebih kecil maka mode regresi lebih bagus dalam bertindak sebagai prediktor penyerapan tenaga kerja dari dapat rata Kesimpulan dan Keterbatasan rata penyerapan tenaga kerja itu sendiri.
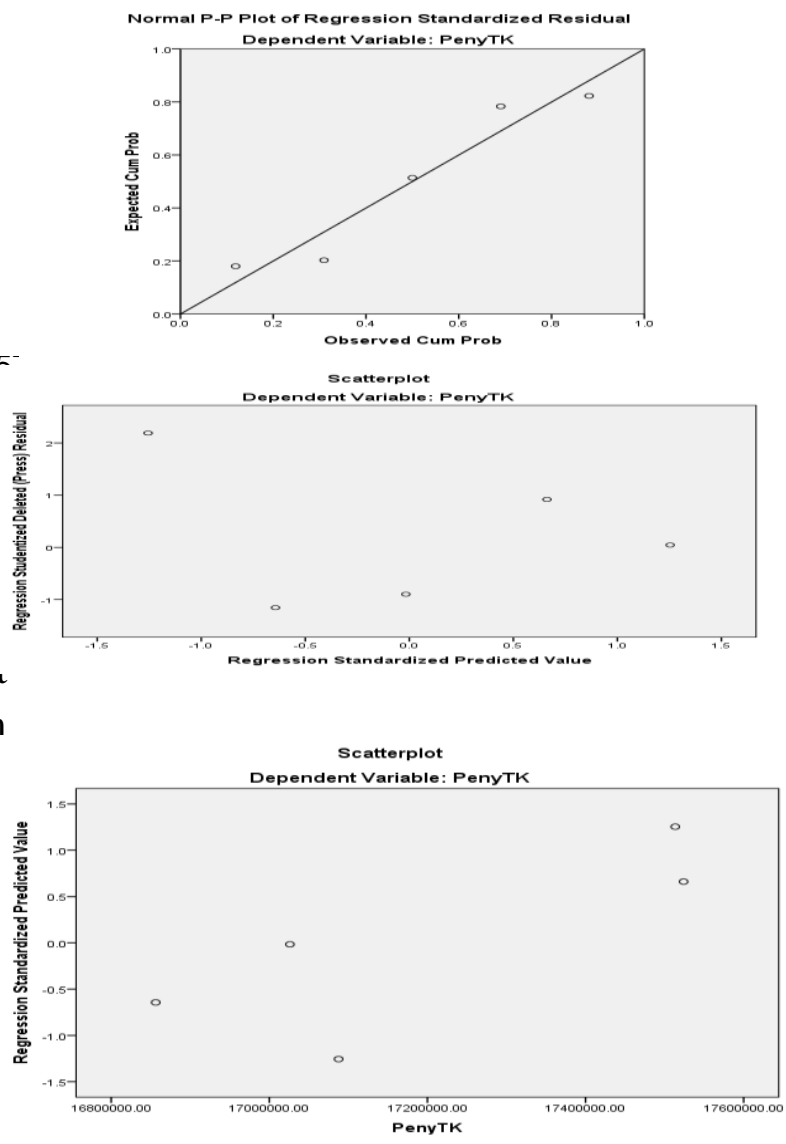

\begin{tabular}{|c|c|c|}
\hline & & $\begin{array}{c}\text { Tabel } 7 \\
\text { Coefficients }^{\mathrm{a}}\end{array}$ \\
\hline \multirow[t]{2}{*}{ Model } & \multicolumn{2}{|c|}{ Unstandardized Coefficients } \\
\hline & $\mathrm{B}$ & Std. Error \\
\hline (Constant) & 16595732.325 & 273327.881 \\
\hline Investasi & .032 & .014 \\
\hline
\end{tabular}

Berdasarkan hasil analisis yang dilakukan data-data di atas dan informasi-informasi yang dikumpulkan selama penelitian berlangsung dan Stis sesuaikan dengan permasalahan-permasalahan Gang dibahas tentang penyerapan tenaga kerja dan investasi. Sejauh data yang dianalisis bahwa investasi berpengaruh positif terhadap penyerapan tenaga kerja. Dengan kata lain apabila investasi meningkat maka peluang penyerapan tenaga kerja juga meningkat.

Sedangkan tabel 7. diperoleh persamaaßeningkatan tersebut dapat dijelaskan dengan regresi $\mathrm{Y}=16595732.325+0,32 \mathrm{X}$, dimana $\mathrm{Y}_{\text {persamaan }}$ regresi adalah $\mathrm{Y}=16595732.325+$ adalah penyerapan tenaga kerja dan $\mathrm{X}$ adalah,32 $\mathrm{X}$. Dalam hal variabel perlu ditambahkan investasi. Sementara gambar dibawah adalah tidak hanya investasi, sehingga analisis terhadap menunjukkan normalitas data yang digunakan. penyerapan tenaga kerja lebih teranalisis secara komprehensif. 
JURNAL ILMIAH EKONOMI ISLAM VOL. 03 NO. 02, 2017

Available at http://jurnal.stie-aas.ac.id/index.php/jie

\section{Daftar Pustaka}

Alexandi, Muhammad Findi dan Marshafeni, Ovilla, Penyerapan Tenaga Kerja Pada Sektor Pertanian Dan Sektor Jasa Pascakebijakan Upah Minimum Di Provinsi Banten (Periode Tahun 2001-2011), Jurnal Manajemen \& Agribisnis, Vol. 10 No. 2, Juli 2013, Institut Pertanian Bogor

Anwar, Arsyad, dkk, 1992, Ekonomi Indonesia Prospek Jangka Pendek dan Sumber Pembiayaan Pembangunan, Gramedia Pustaka Utama, Jakarta.

Aris Ananta, 1990, Ekonomi Sumber Daya Manusia, Lembaga Demografi FEUI, Jakarta.

Baltagi BH. 2005. Econometrics Analysis of Panel Data. England: John Willey \& Sons Ltd.

Bellante, Don \& Mark Janson 2006. Ekonomi Ketenagakerjaan. Jakarta : Lembanga Penerbit Fakultas Ekonomi Universitas Indonesia.

Brealey, R.A, Myers, S.C, Marcus, A.J. 2008. Dasar-dasar Manajemen Keuangan Perusahaan Jilid 1. Jakarta : Penerbit Erlangga.

Dimas Dan Woyanti, Nenik , 2009, Penyerapan Tenaga Kerja di DKI Jakarta, Jurnal Bisnis dan Ekonomi (JBE), Hal. 32 41 Vol. 16, No.1 Fakultas Ekonomi Universitas Diponegoro Semarang

Gudjarati D. 2004. Ekonometrika Dasar. Zain Sumarno dan Zein [penerjemah]. Jakarta: Erlangga.

Halim, Abdul. (2003). Analisis Investasi. Edisi Pertama, Penerbit Salemba Empat : Jakarta.

Hasibuan, Malayu S.P. 1987. Ekonomi Pembangunan dan Perekonomian Indonesia. Bandung : Armico.

Ignatia R. Sitanggang Dan Nachrowi D.Nachrowi, 2004, Pengaruh Struktur Ekonomi pada Penyerapan Tenaga Kerja Sektoral: Analisis Model Demometrik di 30 Propinsi di Indonesia, Jurnal Pembangunan, Juli Vol.5, No 103-133, FEUI, Jakarta.

Kuncoro, Mudrajad. 2004. Otonomi dan Pembangunan Daerah: Reformasi,
Perencanaan, Strategi, dan Peluang. Yogyakarta: Erlangga

Mankiw GN. 2007. Teori Makroekonomi.Edisi ke-6.Nurmawan [penerjemah]. Jakarta: Erlangga.

Mulyadi, 2001, Sistem Akuntansi, Edisi Ketiga, Cetakan Ketiga, Penerbit Salemba Empat, Jakarta.

Payaman, Simanjuntak, 2001, Pengantar Ekonomi Sumber Daya Manusia, LPFEUI, Jakarta.

Puspitaningtyas, Zarah dan Agung W Kurniawan (2012), Prediksi Tingkat Pengembalian Investasi Berupa Devidend Yield Berdasarkan Analisis Financial Ratio. Majalah EKONOMI: Telaah Manajemen, Akuntansi dan Bisnis, Vol. 16, No. 1, hal. 89-98.

Sartono, R.A. 2001. Manajemen Keuangan Teori Dan Aplikasi. Yogyakarta : BPFE.

Soebagiyo, Daryono, 1994, Analisis Hubungan Keuangan Pusat-Daerah terhadap Perkembangan Perekonomian Daerah di Indonesia, Tesis Magister in Economics Pascasarjana Universitas Indonesia, Tidak Dipublikasikan, Jakarta: Fakultas Pascasarjana Bidang Ilmu Ekonomi Universitas Indonesia.

Soebagiyo, Daryono, Kausalitas Granger PDRB Terhadap Kesempatan KerjaDi Provinsi Dati I Jawa Tengah Jurnal Ekonomi Pembangunan, Vol. 8, No. 2, Desember 2007, hal. 177-192

Sukirno, Sadono. 2004. Makro Ekonomi. Edisi Ketiga. Jakarta: PT. Raja Grafindo Persada.

Supriyono, R.A. 1987. Akuntansi Biaya: Perencanaan dan Pengendalian Biaya serta Pembuatan Keputusan. Edisi 2. Yogyakarta: BPFE.

Todaro, Michael. 2000. Pembangunan Ekonomi di Dunia Kelima, Edisi ketujuh, Bumi Aksara. Jakarta.

Zaris, Roeslan .1987. Prespektif Daerah dalam Pembangunan Nasional. LPFE UI, Jakarta 